\title{
Chemical company study shows no dioxin hazard
}

A REPORT to be published this month claims that workers exposed to significant quantities of the animal carcinogen 2,3,7,8-tetrachlorodibenzo-p-dioxin (dioxin) over thirty years ago have a normal incidence of cancer, and a reduced incidence of cardiovascular disease.

The report, published in the American Journal of Occupational Medicine, is an epidemiological survey of workers exposed to dioxin at the Monsanto Chemical Company's site at Nypro, West Virginia. 228 men are known to have been exposed to the chemical: 117 as a result of an accident in the 2,4,5-thrichlorophenol plant on 8 March 1949, and 111 in the routine manufacture of the herbicide $2,4,5-\mathrm{T}$. It documents the mortality indices for 121 of the 228 workers who were traced.

Acknowledging that these results are only part of the story, the report's authors - Judith Zack, an epidemiologist employed by Monsanto and Raymond Suskind, Director of the Institute of Environmental Health at the University of Cincinnati Medical Centre - say that details about the other workers will be published in due course.

Publication of this information by Monsanto is a welcome departure from the company's previous position of treating all information about these workers as confidential. Little was known about the Monsanto accident until July 1976 when a trichlorophenol reactor at the Italian town of Séveso overheated, discharging dioxin over the town and its environs. In the aftermath of Séveso, details began to emerge of at least 16 similar accidents in various parts of the world. Accounts of these accidents and their consequences were requested by Italian officials and scientists anxious to ascertain the consequences of the dioxin exposure for the people of Séveso. Sadly, few companies have been forthcoming; this latest initiative on the part of Monsanto may have the effect of breaking the log jam.

A Monsanto spokesman described this latest report as "reassuring". But it is unlikely to allay all fears about the toxic properties of dioxin. For the results of the Monsanto survey differ from those following surveys of workers exposed to dioxin in West Germany and Holland. Workers known to have been exposed at Badische Anilin und Soda Fabriks' Ludwigshaven site in 1953 are reported to have suffered from a high incidence of gastrointestinal cancer, whilst others contaminated by the chemical at the Amsterdam site of Philips Duphar in 1963 are recorded as having a higher incidence of heart attacks (Nature 19 January 1978, p202).
Zack and Suskind note that their results do not agree with those obtained for German and Dutch workers. They also acknowledge that their survey does not confirm the higher than normal incidence of bronchiogenic carcinoma in workers exposed to dioxin in an accident in Czechoslovakia in 1964.

More recent evidence about the potential carcinogenic properties of dioxin are reported in a survey of Swedish forestry workers published in the British Journal of Cancer 39, 711; 1979. According to its authors, Dr Lennart Hardell and Anita Sandström of the Center of Oncology at the University of Umea, exposure to dioxin contaminated $2,4,5-\mathrm{T}$ or chlorinated phenols could be responsible for the sixfold higher incidence of soft tissue sarcomas seen in these men.

With so much conflicting evidence about the long-term effects of exposure to dioxin, the results of the Monsanto survey - albeit the largest so far - are unlikely to still fears about the risk posed by the chemical. The US Environmental Protection Agency has instituted a temporary ban on 2,4,5-T. Whether or not that ban should be made permanent will be decided after an Agency hearing on the herbicide due to begin on 11 March. The EPA will have to make sense of this conflicting data.

Alastair Hay

\section{No cash to clean up pollution}

MEDITERRANEAN states have come up with only one third of the money needed to maintain the United Nations Environment Programme's Mediterranean pollution programme, UNEP's deputy director Peter Thacher announced in Barcelona on Monday.

Speaking at a meeting of the 17 signatories of the 1975 'Barcelona convention' on pollution in the Mediterranean, Mr Thacher warned "we have today only seven weeks left before we must stop" a number of the programme's activities. Jobs in the programme's 12-strong secretariat are also threatened: "a number of critical posts are filled on contracts which will expire in March unless new cash contributions are received", said Thacher.

A year ago, a meeting of the signatories in Geneva agreed to establish a trust fund of $\$ 6,480,000$ to guarantee the programme for the two years 1979-80. The 17 states, plus the European Commission, were to contribute half, UNEP one quarter, and other UN agencies one quarter in goods and services. A year later, eight countries and the EEC had contributed nothing.

Only five countries have contributed in full, and these were among the smallest and poorest: Algeria, Tunisia, Cyprus, Malta, and Greece, providing $\$ 130,000$ among them.

Among the major countries France has been the most forthcoming, with $\$ 990,000$ of its agreed $\$ 1,564,000$. Italy and Spain, however, which committed themselves at Geneva to spend $\$ 744,000$ and $\$ 412,000$, have so far contributed nothing, said Thacher. In total the countries have contributed $\$ 1,150,000$ against an expected $\$ 3,200,000$.

The next treaty to be signed is the treaty on land-based sources of pollution, the crown jewel of the Mediterranean programme. It was expected that states would sign the protocol in Athens this May and ratify it within two years, but, said Thacher, there were not even enough funds in the kitty to convene the conference.

Moreover land-based sources, particularly of untreated sewage, are the major cause of pollution in the Mediterranean, and would cost according to rough estimates - some $\$ 15$ billion to clean up. UNEP officials have been assuming that this money would be spent over some 10 -20 years, representing a $\$ 1.5$ billion to $\$ 750$ million-a-year spend, 500-1000 times the present - and unachieved - target.

The 'Blue Plan', a proposed high-level economic and sociological study of the likely development of the Mediterranean region to the year 2000 , is also threatened, though not by lack of cash. States had been asked last February to nominate two candidates each for six posts to implement the Blue Plan, but two months past the deadline only seven nominations have been received from seven countries. And, said Thacher, "very few of these candidates have sufficient academic qualifications or experience"'. He concluded that governments were "not serious" about the plan.

- In an extension of the UNEP Regional Seas Programme (of which the Mediterranean programme is a part) to the Caribbean, experts from 23 mainland and island states of the region have agreed to recommend to their governments an action plan on pollution and development. "In its economic and social aspects, the Caribbean Action Plan goes well beyond the Mediterranean Action Plan" says UNEP. The first governmental meeting on the plan will be held in September.

Robert Walgate 